\title{
CLINICAL AND EXPERIMENTAL STUDIES WITH ORAL ALUMINIUM HYDROXIDE
}

\author{
By R. G. BurR, Ph.D., F.R.S.C. and I. Nuseibeh, F.R.C.S. \\ National Spinal Injuries Centre, Stoke Mandeville Hospital, \\ Aylesbury, Buckinghamshire, U.K.
}

\begin{abstract}
Experimental studies in Io paraplegic patients showed highly significant reduction in urinary saturation associated with the oral administration of aluminium hydroxide. Only 50 per cent of urine samples from five patients with calculous disease were actually undersaturated, however.

During clinical studies in 12 patients with renal calculous disease, four had recurrence or growth of calculi while receiving medication, three had no recurrence during therapy, but new stones appeared after the medication was stopped, and five had no growth or recurrence either during therapy or after its cessation.
\end{abstract}

Key words: Aluminium hydroxide; Kidney calculi; Paraplegia.

\section{Introduction}

THE incidence of infected renal calculi in patients with traumatic spinal cord lesions used to be as high as 8.2 per cent (Comarr et al., 1962). Hypercalciuria combined with urinary infection with urea-splitting organisms and urinary stasis are considered to be the main causative factors. At this Centre the incidence has dropped to under 2 per cent, due mainly to the better understanding and care of the urinary system, the use of antibiotics and improved quality of catheters. On the other hand the recurrence rate of infected renal calculi remains high. Among methods we have used in attempting to limit the growth and reduce the recurrence rate of these calculi is reduction in urinary phosphorus excretion.

The oral administration of aluminium hydroxide $(\mathrm{AH})$ or aluminium carbonate following the ingestion of food leads to precipitation of insoluble aluminium phosphate in the gut. Alimentary absorption of phosphorus is impaired leading to reduced excretion of inorganic orthophosphate in urine, possibly via parathyroid hormone mediated inhibition of renal 1,25-dihydroxycholecalciferol production. The use of $\mathrm{AH}$ for the therapy of phosphate stone disease was suggested by Shorr (1945). Good results have been reported, both in bringing about cessation of growth of existing calculi and in preventing recurrence (Pyrah et al., 1956; Lavengood \& Marshall, I972).

The majority of calculi from paraplegic patients consist predominantly of calcium phosphate and magnesium ammonium phosphate (Burr, 1978). An evaluation of this form of therapy in our patients therefore seemed warranted.

\section{Experimental study}

\section{Material and Methods}

Twelve male patients with spinal cord lesions were studied. Six had renal calculi and six had no evidence of stone disease as judged by plain radiographs and pyelography. The aim of the experiment and possible adverse effects were 
explained and informed consent obtained. Two of the patients without calculi withdrew because of abdominal pain or constipation associated with the medication. The mean age of the remaining patients was 35.5 (range 21 to 63) years, and the duration of paralysis at the time of study 8.9 (range $I \frac{1}{2}$ to 20 ) years. Four patients had right-sided radio-opaque renal calculi, one had bilateral radio-opaque calculi and one had a matrix calculus.

$\mathrm{AH}$ was administered in the form of either six Aludrox tablets (Wyeth) or $30 \mathrm{ml}$ Aludrox gel (Wyeth) four times daily, taken I hour after meals and at bedtime. The total $\mathrm{Al}(\mathrm{OH})_{3}$ was $9 \mathrm{~g}$ daily. The patients receiving tablets were instructed to chew, not swallow, them. Normacol Standard granules (Norgine) were also given to reduce constipation. The effect of $\mathrm{AH}$ on phosphate excretion was found to be virtually immediate, and 2-3 days equilibration was therefore allowed between treatment and control periods. In six patients one $\mathrm{AH}$ period was sandwiched between two control periods, in two a control period was sandwiched between two $\mathrm{AH}$ periods, one received $\mathrm{AH}$ first followed by a control period, and in one the control period preceded the $\mathrm{AH}$ period.

Urine collections were made using hibitane ( 20 per cent chlorhexidine gluconate, $\mathrm{pH} 6 \cdot 0-6 \cdot 5)$ as preservative ( $5 \mathrm{ml}$ per litre urine). After measurement of $\mathrm{pH}$ (glass electrode) the urine was acidified $(\mathrm{HCl})$ and a portion stored at $4{ }^{\circ} \mathrm{C}$ for analysis. Sodium and potassium were determined by flame photometry, calcium, ammonium, inorganic phosphate and creatinine by automated spectrophotometry and magnesium by automated fluorimetry. Relative saturation (RS) with respect to brushite (B), octacalcium phosphate (OCP) and magnesium ammonium phosphate (MAP; struvite) were obtained from the nomograms of Marshall \& Robertson (1976), corrected for departures of urinary ionic strength from 0.I5 (Nuseibeh \& Burr, I979; Burr, 1979). Differences between control and AH periods were tested for using Student's $t$ test.

\section{Clinical study}

Twelve male paraplegic patients with renal calculous disease were studied. The mean age at commencement of study was 36.0 (range 24-60) years and duration of paralysis II $\cdot 8$ (range $\mathrm{I} \frac{1}{2}-30$ ) years. Calculous disease affected the left kidney in two patients, the right kidney in seven, and was bilateral in three.

The dosage of $\mathrm{AH}$ was initially the same as for the Experimental Group, but in view of the need to avoid phosphorus depletion as well as to ensure a sufficient dose, periodic determination of urinary phosphate was carried out and the dose of $\mathrm{AH}$ adjusted to keep the urinary phosphate in the range 200 to $400 \mathrm{mg}$ per day. Mild restriction of phosphorus intake was instituted as follows: brown bread, oat and whole wheat cereals and bran were eliminated and the patients were asked to restrict their intake of hard cheese, sardines, nuts, chocolate and cocoa.

Plain radiographs of the abdomen and intravenous pyelograms were obtained at the beginning and end of the period when $\mathrm{AH}$ was taken as well as at the end of the follow-up period and in most cases at other times also.

\section{Experimental study}

\section{Results}

Figures $\mathrm{I}$ and 2 show the mean values for the control and $\mathrm{AH}$ periods for urinary $\mathrm{pH}$, phosphate, calcium $\times$ phosphate product and $\mathrm{RS}$ value for $\mathrm{B}$, OCP and MAP for each patient. In every case the administration of $\mathrm{AH}$ resulted in a significant reduction in phosphate excretion $(\mathrm{P}<0.00 \mathrm{I})$. There were significant 

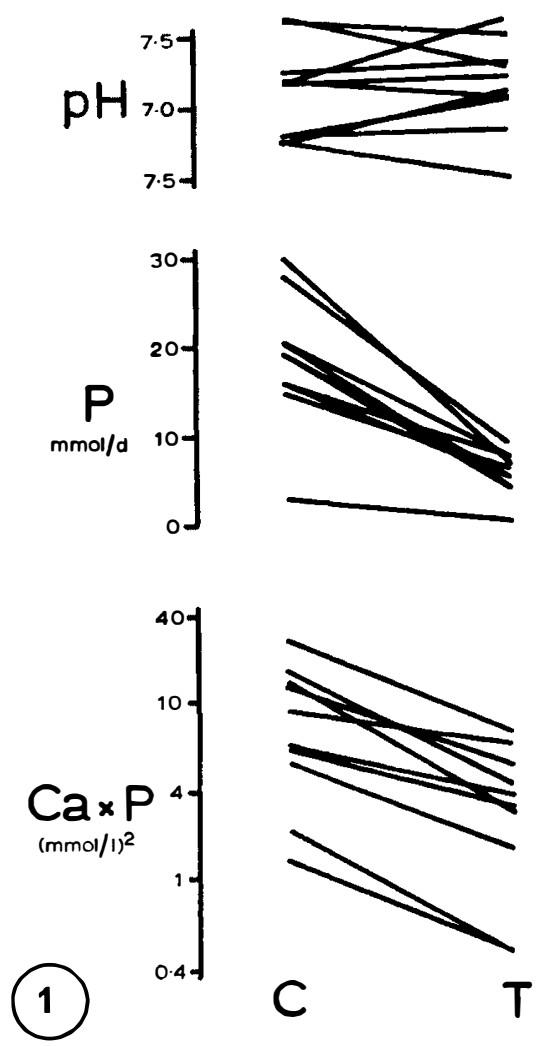
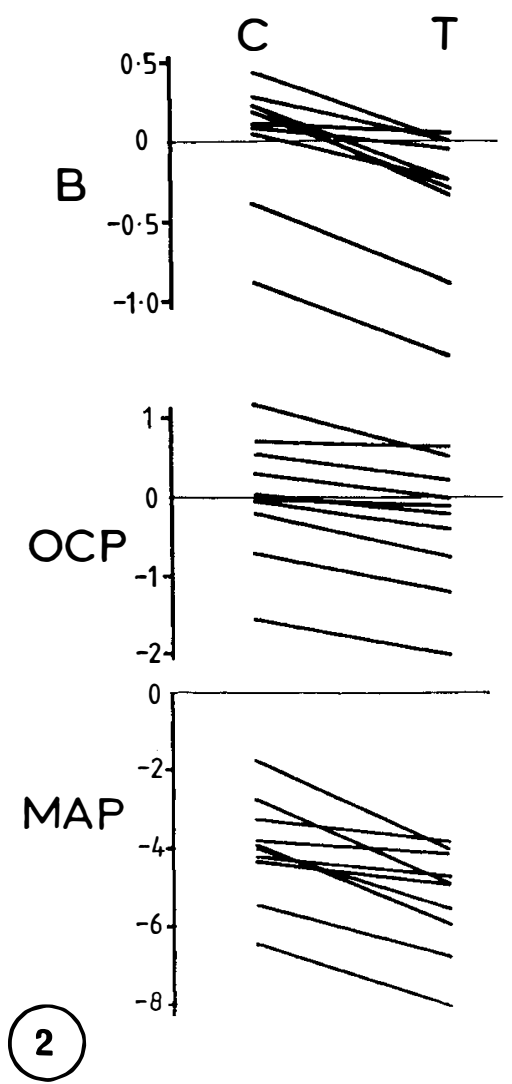

FIG. I

Effects of oral aluminium hydroxide $(9 \mathrm{~g} / \mathrm{d})$ in Io paraplegic patients. Mean values for $\mathrm{pH}$, inorganic phosphate excretion $(\mathrm{P})$ and product of calcium and phosphate concentrations $(\mathrm{Ca} \times \mathrm{P})$ are shown in each patient for control $(\mathrm{C})$ and treatment $(\mathrm{T})$ periods.

FIG. 2

Effects of oral aluminium hydroxide $(9 \mathrm{~g} / \mathrm{d})$ in Io paraplegic patients. Mean values for each patient for the relative saturation of urine with respect to calcium hydrogen phosphate (brushite, B), octacalcium phosphate (OCP) and magnesium ammonium phosphate (struvite, MAP). Results for control (C) and treatment (T) periods are shown.

falls in urinary calcium $\times$ phosphate product and in the RS value for B in nine patients. The RS for OCP was reduced in five and that for MAP in four patients. Changes for all these parameters for the group as a whole were all highly significant $(\mathrm{P}<0 \cdot 00 \mathrm{I})$. Urinary $\mathrm{pH}$ was elevated in two patients but there was no significant change for the group $(\mathrm{P}>0.05)$.

Undersaturation, as indicated by an RS value for OCP of below zero was achieved in six out of the Io patients (mean results for the AH period) and in 15 out of 3024 -hour urine samples from the five patients with radio-opaque calculi.

\section{Clinical study}

The trial was terminated when rapid growth of calculi was observed in two patients. At this time the average duration of therapy was I9 (range 8-26) months. 


\section{TABLE I}

Effects of oral aluminium hydroxide therapy on the course of calculous disease in 12 paraplegic patients.

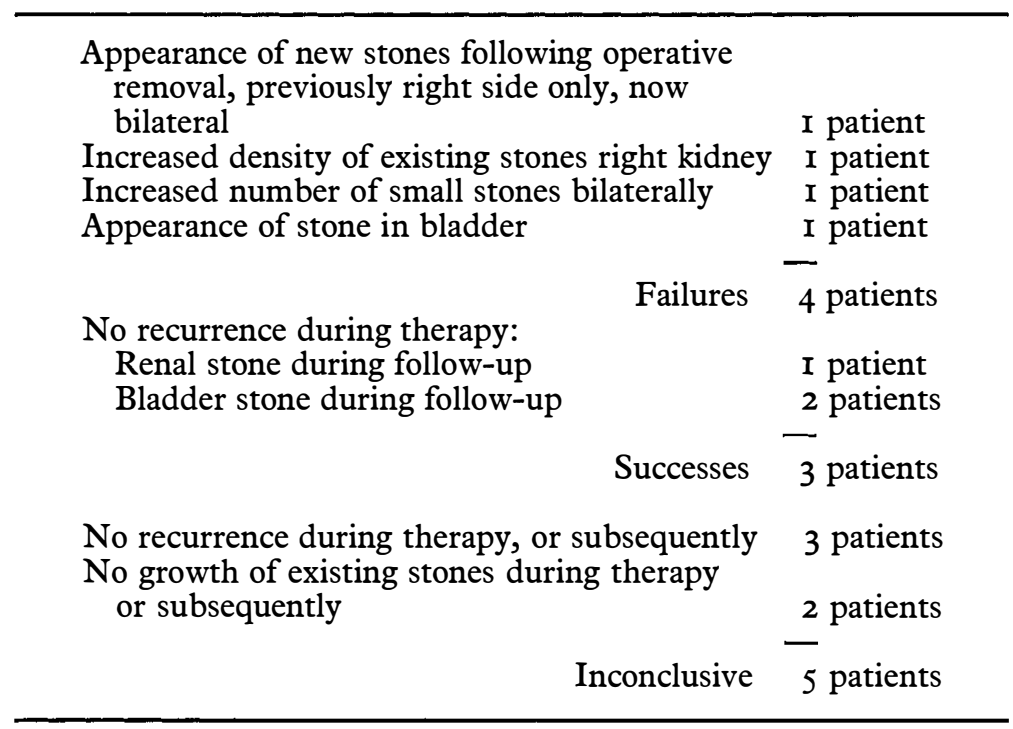

The patients were observed for a further $3 \cdot 7$ (range $3-5$ ) years. Table I summarises the observations. Four patients are considered to be therapeutic failures because new stones appeared in the kidney following previous removal, there was increase in the number or radiological density of stones remaining, or a stone appeared in the bladder during therapy with AH. Three patients were rated as possible successes since there was no evidence of stone recurrence during therapy but calculi recurred during follow-up. The remaining five patients showed no recurrence or growth of existing stones during treatment, but there was no further change during the follow-up period.

\section{Discussion}

The efficacy of oral aluminium hydroxide in binding phosphate in the gut and thus of bringing about a marked decrease in the urinary excretion of phosphate was seen in all patients. It was associated with a significant reduction in the level of saturation of urine with stone-forming phosphates. This decrease was, however, only sufficient to bring about a state of undersaturation in six of the Io patients studied and in 15 of the 30 urine specimens from the five patients with radioopaque calculi (Figure 3).

Elevation of urinary $\mathrm{pH}$ was seen in two patients, a phenomenon we have also observed in healthy volunteers receiving $\mathrm{AH}$. Increased urinary $\mathrm{pH}$ has been reported to result from antacid administration, but not from $\mathrm{AH}$ alone in dosages lower than those used in this work (Gibaldi et al., I974; Tsega et al., 1976). pH rise will tend to counteract the beneficial phosphate-lowering properties of $\mathrm{AH}$.

The clinical results were equivocal. Success and failure rates were similar (three and four patients respectively) and the fact that stone disease did not progress in five patients either during or after the cessation of therapy means that no conclusion can be drawn from them. 


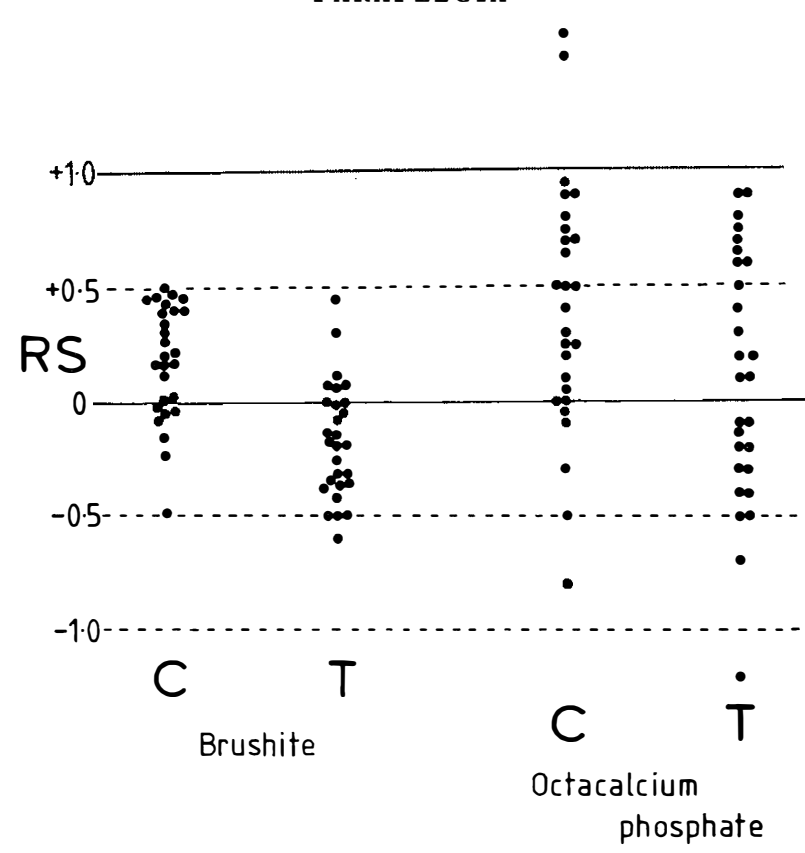

FIG. 3

Effects of oral aluminium hydroxide $(9 \mathrm{~g} / \mathrm{d})$ on the relative saturation (RS) of urine with respect to brushite and octacalcium phosphate in five paraplegic patients with radio-opaque renal calculi. Results during control and treatment periods are shown. Each dot represents one 24-hour urine sample.

Effective medical therapy for calculous disease probably depends on keeping the urine in a state of undersaturation. We attribute our present therapeutic failures principally to this cause. Definite achievement of undersaturation is especially important during AH therapy since reduction in orthophosphate excretion is probably parallelled by lowered urinary concentration of inorganic pyrophosphate, an inhibitor of calcium phosphate crystal formation (Russell \& Fleisch, I973).

In retrospect, more success might have been achieved if we had used a lower target value for urinary phosphate. This would have necessitated closer patient monitoring to reduce the risk of phosphorus depletion (Spencer \& Lender, 1979), and would also have tended to reduce patient compliance.

The quantity of medication required is large and not easy to take. Constipation is frequently made more troublesome in patients who already require aperients. The original Shorr regimen involved extensive dietary modification, including reduction in protein intake which is undesirable for some of our patients. Other workers have emphasised the need for strict patient surveillance and have noted a strong relationship between patient compliance and the clinical effectiveness of the Shorr regimen (Pyrah et al., I956; Lavengood \& Marshall, I972).

\section{Conclusion}

A medical therapy for urinary stone disease which does not bring about sustained urinary undersaturation is unlikely to be effective clinically. In our hands this has been the case with oral aluminium hydroxide medication. 


\section{SUMMARY}

Aluminium hydroxide given orally leads to a reduction in urinary phosphate excretion. Success in the treatment of phosphate stone disease has been reported using this agent. We report experimental studies involving measurements of urinary saturation in Io paraplegic patients and clinical experience, including radiological assessment, in 12 patients with renal calculi.

Highly significant reduction in the relative saturation of urine with stoneforming phosphates were observed in response to the administration of aluminium hydroxide. A state of undersaturation was only achieved in 50 per cent of 24-hour urine samples from five patients with phosphatic renal stones.

The clinical study was terminated when rapid stone growth occurred in two patients receiving aluminium hydroxide. Progress in the 12 patients was reviewed 3-5 years after cessation of therapy which lasted an average of 19 months. Four had recurrence or growth of calculi while receiving medication, three had no recurrence during therapy but new stones appeared after the medication was stopped, and five had no growth or recurrence either during therapy or after its cessation.

\section{RÉSUMÉ}

Si l'hydrate d'alumine est donnée par voie orale il produit une réduction d'excrétion du phosphate urinaire. Le succès de cette traitement pour empêchment les calculs urinaire à été reporté. Nous relatons les études experimentales lequel enveloppe les mésures de la saturation urinaire en Io patients paraplégique et notre expérience clinicale lequel à compris une évaluation radiologique en I 2 patients avec les calculs rénals.

Une réduction très significante en la saturation relative de l'urine des phosphates, que produit les calculs été observée avec l'administration d'hydrate d'alumine. Une situation de sous-saturation été accomplie avec $50 \%$ des samples de l'urine pendant une élimination de $24 \mathrm{hrs}$ par cinq patients avec les calculs rénal que sont composés de phosphate.

Les études clinicales été terminées quand une grandissement rapide des calculs été recurrée en deux patients qui a reçu l'hydrate d'alumine. Le progrès en 12 patients sont revisés après 3 a 5 ans après le cessation du traitement qu'a duré ou comme moyenne pour I 9 mois. Quatre patients à ou une grandissement des calculs pendant le reçu de la médication. Trois patients à où aucune récurrence pendant le thérapie mais les calculs nouvelles sont apparée après le cessation du médication, et cinq patients à où ni grandissement ni récurrence pendant le thérapie ou après ce cessation.

\section{ZUSAMMENFASSUNG}

Wenn Aluminiumhydroxid oral gegeben wird, kommt es zu einer Reduktion der Harnphosphat Exkretion. Behandlungserfolge bei Phosphatstein-erkrankungen wurden beschrieben, wobei dieses Medikament verabreicht worden war. Wir berichten über experimentelle Studien, in denen Messungen der Harnanreicherung bei Io Paraplegikern vorgenommen wurden und die dadurch gewonnene klinische Erfahrung. Auch radiologische Begutachtungen wurden vorgenommen bei 12 Patienten mit Nierensteinen.

Eine höchst signifikante Reduktion der relativen Harnanreicherung mit steinbildenden Phosphaten wurde beobachtet als Respon auf die Verabreichung von Aluminiumhydroxid. Eine zu geringe Anreicherung wurde nur in $50 \%$ der 24 -Stundenharne von 5 Patienten mit Phosphatnierensteinen erreicht.

Die klinische Studie wurde abgebrochen, als es bei 2 Patienten zu einem rapiden Steinwachstum unter Aluminiumhydroxid-Behandlung kam. Der Behandlungserfolg bei den 12 Patienten wurde 3-5 Jahre nach der beendigung der Behandlung, die im Durchschnitt ca. I9 Monate durchgeführt wurde, begutachtet. Vier dieser Patienten hatten ein erneutes Steinwachstum während der Behandlung, 3 Patienten hatten kein erneutes Steinwachstum während der Behandlung, jedoch erneute Steinbildung nach Beendigung der Behandlung und weitere 5 Patienten hatten kein weiteres Steinwachstum während der Behandlung und nach Beendigung der Behandlung. 
Acknowledgement: Experimental studies on five of the patients reported here were carried out as part requirement for Ph.D. degree for one of us (R.G.B.). We thank Dr A. Barr for the statistical calculations, Dr L. C. A. Nunn for the sodium and potassium determinations and Pamela Smith for technical assistance.

\section{REFERENCES}

BURR, R. G. (1978). Urinary calculi composition in patients with spinal cord lesions. Arch. Phys. Med. Rehabil., 59, 84-88.

BURR, R. G. (I979). Some biochemical aspects of urinary tract stone formation in paraplegic patients. Ph.D. Thesis, University of London.

ComARR, A. E., KAWAICHI, G. \& Bors, E. (I962). Renal calculosis of patients with traumatic cord lesions, f. Urol., 87, 647-657.

Gibaldi, M., GRUNDHOFER, B. \& LEVy, G. (1974). Effect of antacids on pH of urine, Clin. Pharm. Ther., 16, 520-525.

LAVENGOOD, R. W. \& MARShALL, V. F. (1972). The prevention of renal phosphatic calculi in the presence of infection by the Shorr regimen, f. Urol., 108, 368-37I.

MARShall, R. W. \& Robertson, W. G. (I976). Nomograms for the estimation of the saturation of urine with calcium oxalate, calcium phosphate, magnesium ammonium phosphate, uric acid, sodium acid urate, ammonium acid urate and cystine, Clin. Chim. Acta, 72, 253-260.

NUSEIBEH, I. \& BURR, R. G. (1979). The effects of varying water intake and of other measures on the relative saturation of stone-forming salts in the urine of spinal cord patients, Paraplegia, 17, 363-370.

Pyrah, L. N., Raper, F. P. \& Smith, I. B. (I956). The use of aluminium hydroxide to prevent recurrent renal calculi, Br. F. Urol., 28, 23I-239.

Russell, R. G. G. \& FleisCH, H. (I973). Inhibitors in urinary stone disease: role of pyrophosphate, in International Symposium on Renal Stone Research, Madrid, I972. L. Cifuentes Delatte, A. Rapado \& A. Hodgkinson (eds.), pp. 307-3I2. Karger, Basel.

SHORR, E. (1945). The possible usefulness of estrogens and aluminium hydroxide gels in the management of renal stone, $\mathcal{F}$. Urol., 53, 507-520.

SPENCER, H. \& LENDER, M. (I979). Adverse effects of aluminium-containing antacids on mineral metabolism, Gastroenterology, 76, 603-606.

Tsega, E., Tegenem, N. \& Tessema, D. (1976). The effects of antacids on urinary $\mathrm{pH}$, Ethiop. Med. F., 14, I79-I 84. 